\title{
Optimization of substrate preparation for oyster mushroom (Pleurotus ostreatus) cultivation by studying different raw materials and substrate preparation conditions (composting: phases I and II)
}

\author{
Fabrício Rocha Vieira ${ }^{1,2}$ (1) $\cdot$ Meire Cristina Nogueira de Andrade ${ }^{1}$
}

Received: 15 June 2016/Accepted: 27 September 2016/Published online: 30 September 2016

(C) Springer Science+Business Media Dordrecht 2016

\begin{abstract}
In recent years, oyster mushroom (Pleurotus ostreatus) has become one of the most cultivated mushrooms in the world, mainly in Brazil. Among many factors involved in a mushroom production, substrate preparation is the most critical step, which can be influenced by composting management techniques. Looking forward to optimizing the substrate preparation process, were tested different composting conditions ( 7 and 14 days of composting with or without conditioning), potential raw materials (decumbens grass, brizantha grass and sugarcane straw) and nitrogen supplementation (with or without wheat bran) on oyster mushroom yield and biological efficiency (BE). The substrate composted for 7 days with conditioning showed higher yield and biological efficiency of mushroom (24.04 and $100.54 \%$, respectively). Substrates without conditioning (7 and 14 days of composting) showed smaller mushroom yield and biological efficiency. Among the raw materials tested, brizantha grass showed higher mushroom yield followed by decumbens grass, sugarcane straw and wheat straw $(28.5,24.32,23.5$ and $19.27 \%$, respectively). Brizantha grass also showed higher biological efficiency followed by sugarcane straw, decumbens grass and wheat straw $(123.95,103.70,96.90$ and $86.44 \%$, respectively). Supplementation with wheat bran improved yield and biological efficiency in all substrate formulations tested; thus, oyster mushroom yield and
\end{abstract}

Fabrício Rocha Vieira

vieira.cogu@gmail.com

1 Department of Plant Production, College of Agricultural Sciences, Sao Paulo State University, Jose Barbosa de Barros - 1780, Botucatu, SP 18610-307, Brazil

2 Mushroom Research Center, The Pennsylvania State University, University Park, PA 16802, USA biological efficiency were influenced by substrate formulation (raw materials), supplementation and composting conditions.

Keywords Composting · Pleurotus ostreatus · Yield . Supplement $\cdot$ Raw materials

\section{Introduction}

In the last 10 years, oyster mushroom (Pleurotus ostreatus) has become one of the most cultivated mushrooms in the world, mainly in Brazil (Lee et al. 2002; Sánchez 2010; Royse 2013). There are many reasons for this production increase, certainly, the capability of oyster mushroom to grow in a wide range of agricultural and forest wastes through different production methods, as well as its nutritional and medicinal benefits are the highlights (Bonatti et al. 2004; Chang and Miles 2004; Sánchez 2010). In addition, importation of canned champignon (Agaricus bisporus) from Asia at low-cost showed a massive migration of Brazilians champignon growers to oyster mushroom cultivation. $^{1}$

In a large-scale mushroom production, substrate preparation is the most critical and expensive step, which demand years of experience, knowledge and investment in infrastructure (Van Griensven 1988; Chang and Miles 2004). A survey carried out with producers in Sao Paulo (Brazil's largest producer state) during 2009 to 2014

\footnotetext{
$\overline{1}$ A personal communication with mushroom growers of the Sao Paulo state, Brazil.
} 
showed that lack of knowledge about substrate preparation and poor technical support is a big challenge for oyster mushroom growers. ${ }^{2}$

Oyster mushroom (primary decomposer) has a powerful enzymatic machinery allowing then to grow in a wide range of agro-wastes through different substrate preparation methods (Chang and Miles 2004; Sánchez 2010). However, the mushroom industry has employed the composting substrate preparation method because is less expensive, decrease chances of subsequent infections with competitor species (Choi 2007; Hernández et al. 2003; Vajna et al. 2010), and allows the utilization of existing champignon farm infrastructure. ${ }^{2,3}$

Substrate preparation through composting is carried out in two phases: Phase I-carried out in rick (outdoor) or bunker (forced aeration system, indoor). Self-heating by microbial activity can reach $80^{\circ} \mathrm{C}$ in few days. This intense microbial activity causes the breakdown of complex carbohydrates (e.g. cellulose, hemicellulose and lignin) releasing nutrients for mushroom cultivation; Phase II-carried out in a controlled environment (pasteurization tunnel) in two stages, pasteurization and conditioning. Pasteurization stage is responsible to kill insect, nematodes, competitor fungi and others pests (temperature $\sim 60^{\circ} \mathrm{C}$ ) and; conditioning is necessary to reduce the free ammonia formed during phase I and to improve the biological environment of substrate (beneficial microbiota to mushroom cultivation) (Van Griensven 1988; Straatsma et al. 1994, 2000; Oei 2003).

Substrate preparation through composting was developed for champignon cultivation (secondary decomposer) and has been constantly improved in the last 70 years (Sinden and Hauser 1950; Van Griensven 1988; Sharma et al. 2000; Straatsma et al. 2000). On the other hand, limited information's are available about substrate preparation through composting to oyster mushroom cultivation (primary decomposer), which has physiological characteristics completely different than champignon. Among many factors regulatory of a mushroom production, composting management techniques, as well as raw materials and supplementation are crucial to reach optimum cost-effective and high-yield mushroom (Oei 2003; Chang and Miles 2004; Choi 2007). Looking forward to optimizing the composting process to oyster mushroom cultivation, were tested different composting conditions, potential raw materials and substrate supplementation on mushroom yield and biological efficiency.

\footnotetext{
${ }^{2}$ A survey carried out by technical assistance with oyster mushroom growers, SEBRAETec program (Expert in Micro Enterprises and Small Businesses in Brazil).

3 A personal communication with mushrooms producers of Brazil, Europe, and North America.
}

\section{Materials and methods}

\section{Pleurotus ostreatus strains and spawn preparation}

The oyster mushroom strains were collected in a commercial cultivation (Sao Paulo state, Brazil), renamed (POS 09/101 and POS 09/102) and appropriately storage in the fungal genetic bank at the Mushroom Module, Sao Paulo State University (Department of Plant Production). Both strains were characterized by 'Random Amplification of Polymorphic DNA-RAPD and tested to mushroom production performance previously (Vieira et al. 2012). Spawn was based on wheat grains, which were boiled in water for $35 \mathrm{~min}$ and $\mathrm{pH}$ adjusted to 7 adding $10 \mathrm{~g} \mathrm{~kg}^{-1}$ calcium carbonate and $10 \mathrm{~g} \mathrm{~kg}^{-1}$ gypsum (wet grains). Thermoresistant plastic bags were filled with $1 \mathrm{~kg}$ cooked grains and autoclaved for $4 \mathrm{~h}$ at $121{ }^{\circ} \mathrm{C}$. After cool down, these sterile grains were inoculated with $P$. ostreatus mycelia (10 medium culture pieces, PDA-Potato Dextrose Agar) and incubated at $25{ }^{\circ} \mathrm{C}$ for 15 days in darkness (Royse and Schisler 1987).

\section{Substrate preparation (composting phases I and II)}

Substrate applied to evaluated oyster mushroom production under different substrate composting conditions was based on sugarcane straw (Saccharum officinarum), sugarcane bagasse, wheat bran and rice bran (Table 1). Two substrate ricks $(2 \mathrm{~m}$ width $\times 3 \mathrm{~m}$ length $\times 1.2 \mathrm{~m}$ height $)$ were composted for different periods (7 and 14 days). Briefly, was composted a rick for 7 days and then assembled the second rick (14 days of phase I), allowing the phase II execution at the same time for both substrates rick (Fig. 1). At the end of phase I, thermo-resistant grid plastic boxes were filled with $\sim 10 \mathrm{~kg}$ substrate and randomly placed in an acclimatized chamber model Dalsem Mushroom to phase II execution (chamber with environmental control through VEC 32 software-by Dalsem, Woudseweg 9, The Netherlands). Phase II was adjusted following pasteurization at $59.5 \pm 1{ }^{\circ} \mathrm{C}$ for $8 \mathrm{~h}$ and conditioning at $46.5 \pm 1{ }^{\circ} \mathrm{C}$ for 3 days (Fig. 1).

Different substrate formulations were prepared following the shorter composting condition applied previously (7 days of composting with conditioning) to evaluate potential raw materials and supplementation level on mushroom yield (Fig. 1). Were formulated substrates based on decumbens grass (Brachiaria decumbes), sugarcane straw, brizantha grass (Brachiaria brizantha), wheat straw (Triticum aestivum), and sugarcane bagasse, supplemented or not with wheat bran, totalizing 8 different substrate formulations (Table 2). 
Table 1 Substrate applied to oyster mushroom cultivation in different composting conditions

\begin{tabular}{lllll}
\hline Raw material & \multicolumn{2}{l}{$\mathrm{Kg}^{1}$} & \multicolumn{2}{c}{ C/N ratio } \\
\cline { 2 - 4 } & Dry mass & N content & C content & \\
\hline Sugarcane bagasse & 140.00 & 0.48 & 68.46 & $142.6 / 1$ \\
Sugarcane straw & 164.00 & 0.98 & 83.80 & $85.5 / 1$ \\
Rice bran & 21.50 & 0.73 & 14.87 & $20.4 / 1$ \\
Wheat bran & 18.00 & 0.49 & 9.11 & $19 / 1$ \\
Limestone & 3.00 & - & - & - \\
Gypsum & 3.00 & - & - & - \\
Total & 349.50 & 2.68 & 176.24 & - \\
Initial C/N ratio-phase I & - & - & - & $65 / 1$ \\
\hline
\end{tabular}

${ }^{1} \mathrm{~N}$ content- - total nitrogen; $\mathrm{C}$ content- total carbon; $\mathrm{C} / \mathrm{N}$ ratio-carbon and nitrogen ratio

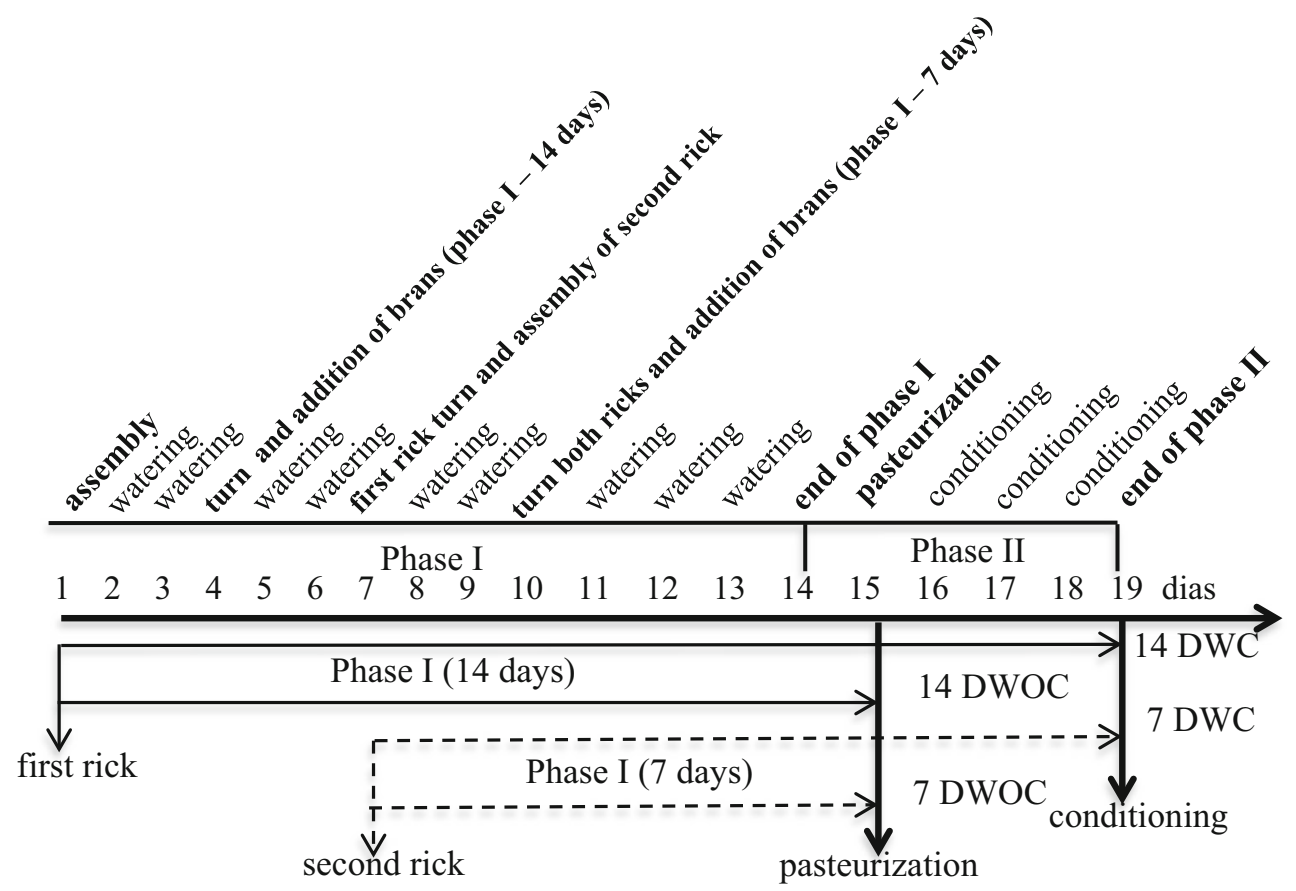

Fig. 1 Composting under different conditions (phases I and II). Substrates: 7 DWOC -7 days of phase I without conditioning; 7 DWC -7 days of phase I with conditioning; 14 DWOC-14 days of phase I without conditioning; 14 DWC_-14 days of phase I with conditioning

Table 2 Substrate formulations based on different raw materials with or without supplementation

\begin{tabular}{|c|c|c|c|c|c|c|c|}
\hline Substrate $^{1}$ & $\mathrm{C} / \mathrm{N}$ ratio & Sugarcane bagasse & Decumbens grass & Sugarcane straw & Brizantha grass & Wheat straw & Wheat bran \\
\hline SDEC & $60: 1$ & 13.03 & 47.96 & - & - & - & 8.9 \\
\hline SCAN & $60: 1$ & 19.55 & - & 48.48 & - & - & 8.9 \\
\hline SBRI & $60: 1$ & 39.09 & - & - & 48.51 & - & 8.9 \\
\hline SWHE & $60: 1$ & 13.03 & - & - & - & 48.87 & 8.9 \\
\hline SDEC & $90: 1$ & 13.03 & 47.96 & - & - & - & - \\
\hline SCAN & $90: 1$ & 19.55 & - & 48.48 & - & - & - \\
\hline SBRI & $90: 1$ & 65.15 & - & - & 48.51 & - & - \\
\hline SWHE & $90: 1$ & 13.03 & - & - & - & 48.87 & - \\
\hline
\end{tabular}

${ }^{1}$ SDEC — decumbens grass, SCAN—sugarcane straw, SBRI—brizantha grass and, SWHE—wheat straw. Substrate formulations were calculated on dry basis $(\mathrm{kg})$ 
Fig. 2 Composting temperature (phase I). Peak heating of substrate ricks are indicated per arrows on top of graphic (7 D7 days of phase I; $14 \mathrm{D}$ 14 days of phase I, following experimental design mentioned in Fig. 1)

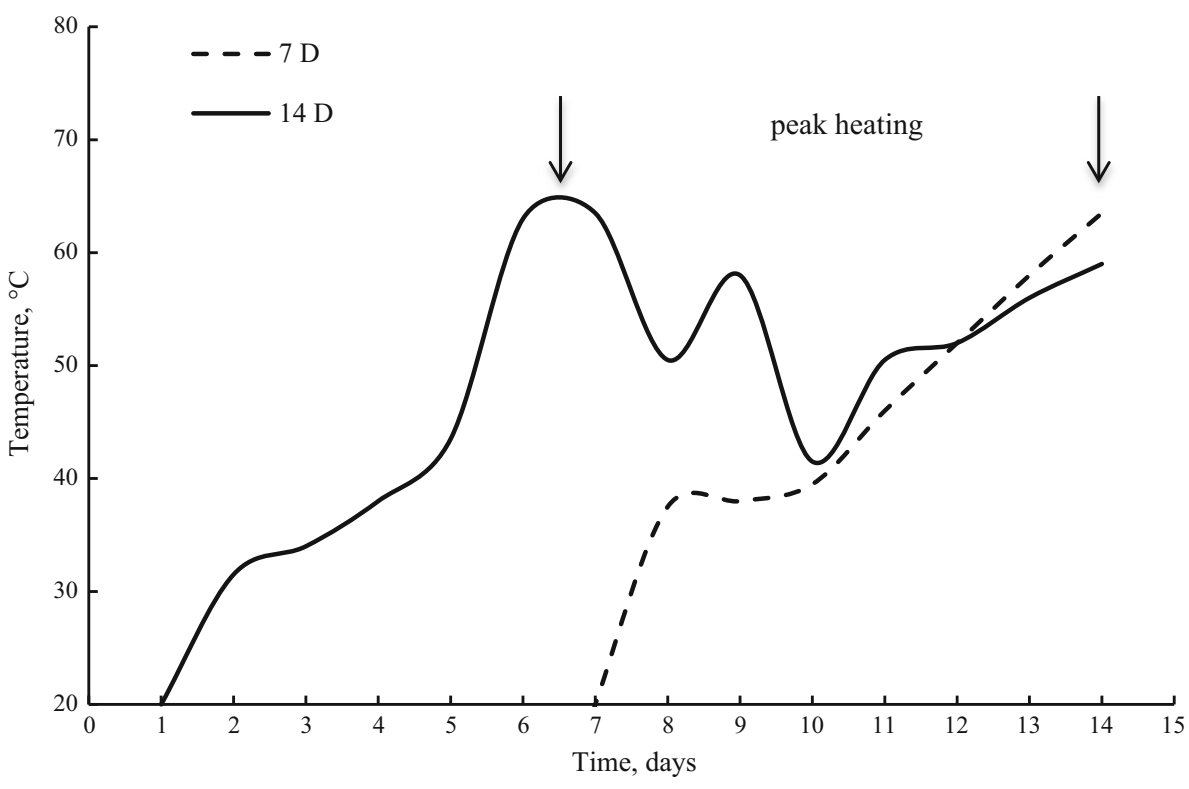

\section{Spawning, spawn run and mushroom production}

Spawning was carried out manually applying $20 \mathrm{~g} \mathrm{~kg}^{-1}$ spawn/kilogram of substrate (wet substrate, $68 \%$ of moisture). Plastic bags (grey color, rectangular block) were filled with $8 \mathrm{~kg}$ of spawned substrate and placed in an acclimatize chamber (Model Dalsem Mushroom, mentioned above) to spawn run at $25 \pm 1{ }^{\circ} \mathrm{C}, 85 \%$ humidity, in darkness for 13 days (full colonization). The plastic bags had 24 holes of $1 \mathrm{~cm}$ of diameter placed $10 \mathrm{~cm}$ each other. After complete substrate colonization, those blocks were transferred to a production room, which has humidification and gases exchange system. Thermal shocks to induce mushroom fructification was under environmental temperature, which ranged between 15 and $29^{\circ} \mathrm{C}$ (night and daytime). Relatively humidity was managed between 70 and $90 \%$ through nebulization. Mushroom harvest started 5 days at the end of spawn run. Mushrooms were harvested manually when they reached the range size between 2 and $3.5 \mathrm{~cm}$ of diameter pileus, counted and weighed before yield and biological efficiency (BE) calculation.

\section{Substrate and mushroom production analysis}

Were collected substrate samples at the beginning and at the end of phase I, after pasteurization and conditioning (4 sampled points). Samples were dehydrated at $105^{\circ} \mathrm{C}$ for $72 \mathrm{~h}$, milled in knife mill with 30 mesh sieve and stored at $-20{ }^{\circ} \mathrm{C}$ until physicochemical analyses. To evaluate organic matter, carbon, nitrogen and $\mathrm{C} / \mathrm{N}$ ration were used loss ignition and Kjeldahl (Brasil 2007). The $\mathrm{pH}$ was calculated using $10 \mathrm{~g}$ of substrate (fresh substrate) added at $50 \mathrm{ml}$ of $\mathrm{CaCl}_{2} 0.01 \mathrm{~mol} / \mathrm{L}$, stirring for $30 \mathrm{~min}$ and subsequently measured with a $\mathrm{pH}$ meter (model Micronal B474) (Brasil 2007). Crude energy was measured by calorimeter bomb method (model IKA C200). Soluble sugar was measured by colorimetric method modified (glucose and xylose standard curve) to determine soluble carbohydrate (Johnson et al. 1966). Temperature during the phase I composting was measured by thermometer (PT $100)$ in six different points in the ricks. Mushroom yield was calculated by fresh weight mushroom/fresh weight substrate $\times 100$ and BE fresh weight mushroom/dry weight substrate $\times 100$ (Royse et al. 2004).

\section{Statistical analysis}

Two statistical designs were applied to data comparison under different composting conditions. Mushroom production (yield and biological efficiency) was a factorial $2 \times 2$ (two phase I periods $\times$ two phase II periods) with 10 replicates. Physicochemical composition of substrate was a factorial $2 \times 4$ ( 2 substrate $\times 4$ stages of composting) with 3 replicates. Comparisons among different substrate formulations (yield and biological efficiency) were designed a factorial $2 \times 4(2 \mathrm{C} / \mathrm{N}$ ratio $\times 4$ raw materials $)$ with 13 replicates. Means were analyzed by ANOVA (Tukey test, $5 \%$ ).

\section{Results}

The temperature of substrate under different composting conditions (phase I) reached the peak heating on day 7 (Fig. 2), for both ricks (7 and 14 days). Among all substrate physicochemical analysis, organic matter and $\mathrm{C} / \mathrm{N}$ 

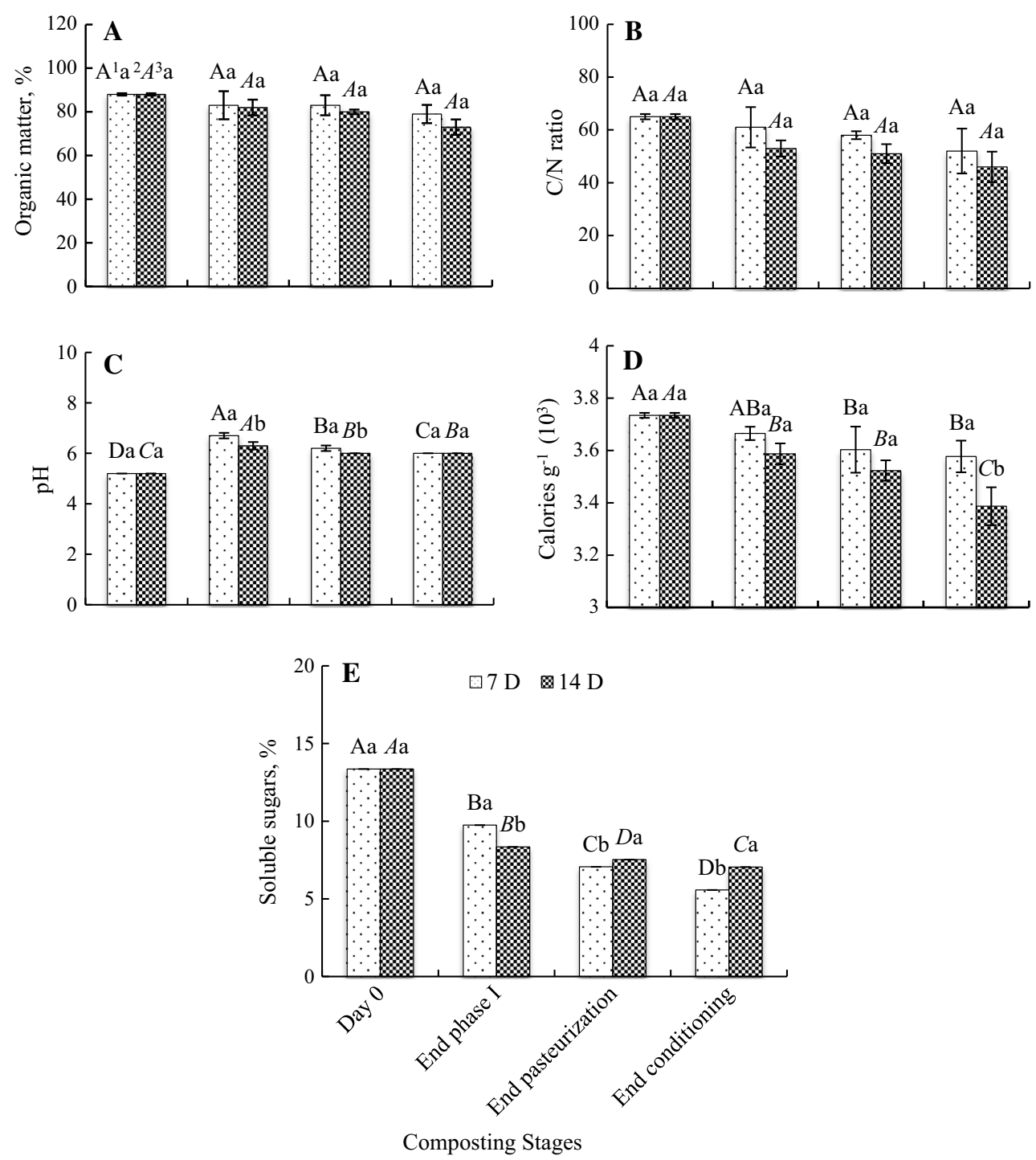

Fig. 3 Physicochemical composition of the substrate during composting (phases I and II). a-organic matter; $\mathbf{b}-\mathrm{C} / \mathrm{N}$ ratio; $\mathbf{c}-\mathrm{pH}$; d-crude energy (calories $\mathrm{g}^{-1}$ ); $\mathbf{e}$ - soluble sugars. Dry basis substrate. $7 \mathrm{D}-$ seven days of phase I; $14 \mathrm{D}-14$ days of phase I.

${ }^{1}$ Means followed by same uppercase letter indicate no statistical

ratio were not influenced by different composting conditions (Fig. 3a, b), while crude energy, soluble sugars and pH showed significant changes (Fig. 3c-e).

Mushroom yield and BE were significantly influenced under different substrate preparation conditions (Fig. 4). The conditioning absence decreased mushroom yield and $\mathrm{BE}$ in the substrate composted for 7 days (phase I). However, conditioning absence showed not influenced on mushroom yield in the substrate composted for 14 days, only to BE. The different phase I conditions (7 and 14 days) with conditioning showed not influence on mushroom yield and BE.

Different substrate formulations showed statistically difference on mushroom yield and BE (Fig. 5). Substrate difference across $7 \mathrm{D}$ of composting; ${ }^{2}$ Means followed by same italic uppercase letter indicate no statistical difference across $14 \mathrm{D}$ of composting; ${ }^{3}$ Means followed by same lowercase letter indicate no statistical difference between $7 \mathrm{D}$ and $14 \mathrm{D}$ at the same composting stage

based on brizantha grass with supplementation showed higher mushroom yield and BE (28.50 and $123.95 \%$, respectively), while non supplementation decreased mushroom yield and $\mathrm{BE}$ to 16.02 and $77.43 \%$, respectively (Fig. 5). Substrate based on wheat straw in these experimental conditions showed smaller yield, with or without supplementation, 19.27 and $12.26 \%$, respectively (Fig. 5). Biological efficiency also was smaller in wheat straw substrate, 86.40 and $65.57 \%$ with and without supplementation, respectively (Fig. 5).

All substrates supplemented with wheat bran $(\mathrm{C} / \mathrm{N}$ ratio of 60:1) showed higher temperature during phase I composting than substrates without supplementation (Fig. 6a, b). Brizantha grass substrate showed higher temperature 


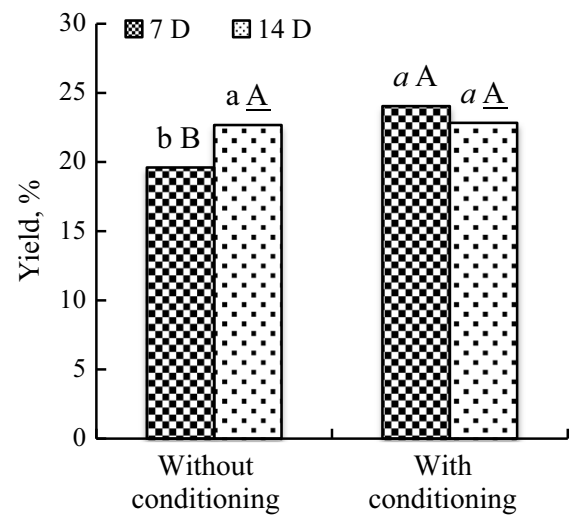

Fig. 4 Yield and biological efficiency (BE) of Pleurotus ostreatus cultivated under different composting conditions. The legend on top of graphic indicates how long substrates were composted (7 and 14 days, $7 \mathrm{D}$ and $14 \mathrm{D}$, respectively). Means followed by same lowercase letter indicate no statistical difference at the same phase II

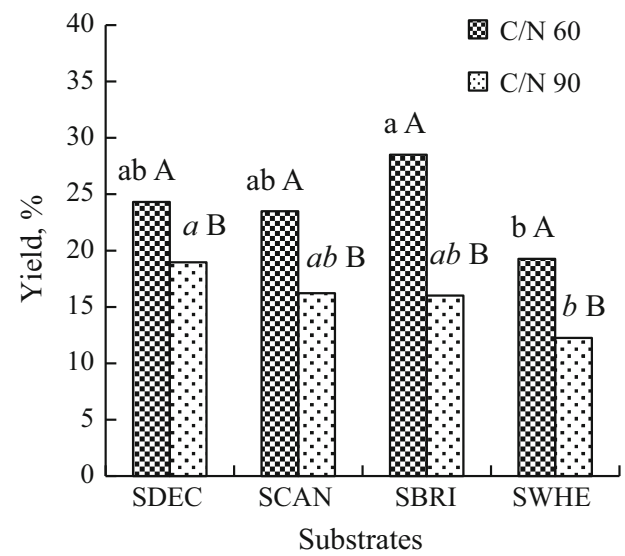

Fig. 5 Yield and biological efficiency (BE) of Pleurotus ostreatus cultivated in different substrate formulations with or without supplementation. Substrates: SDEC - decumbens grass; SCAN—sugarcane straw; SBRI-brizantha grass; SWHE-wheat straw. Substrate supplementation: $\mathrm{C} / \mathrm{N}$ ratio of $60: 1$-with supplementation; $\mathrm{C} / \mathrm{N}$ ratio of 90:1-without supplementation. Means followed by same lowercase

followed by decumbens grass, sugarcane straw and wheat straw (Fig. 6a, b). Brizantha grass also showed higher $\mathrm{C} / \mathrm{N}$ ratio reduction during composting, while wheat straw substrate showed lower $\mathrm{C} / \mathrm{N}$ ratio reduction (Fig. 6c, d).

\section{Discussion}

Biological substrate transformation during composting process can be monitored by physicochemical analysis such as, organic matter, $\mathrm{pH}, \mathrm{C} / \mathrm{N}$ ratio, soluble sugars, crude energy, temperature, among others (Sharma et al. 2000; Lyons et al. 2006). Temperature measurement during composting (phase I) indicates an intense microbial activity (Fig. 1). Mesophilic and thermophilic microorganisms

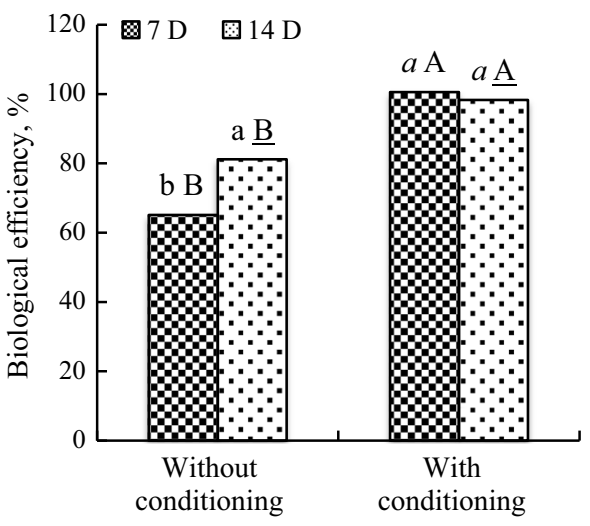

condition (7 D and $14 \mathrm{D}$ with conditioning-normal lowercase; $7 \mathrm{D}$ and $14 \mathrm{D}$ without conditioning-italic lowercase). Means followed by same uppercase letter indicate no statistical difference at the same phase I condition (7 D without and with conditioning-normal uppercase; $14 \mathrm{D}$ without and with conditioning_bold uppercase)

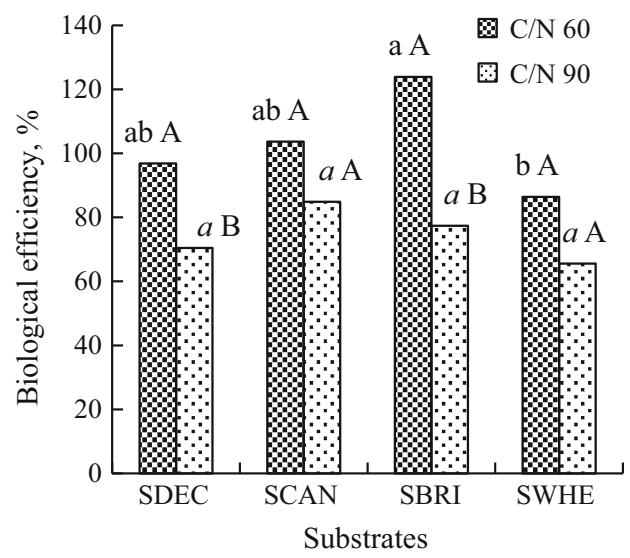

letter indicate no statistical difference at the same $\mathrm{C} / \mathrm{N}$ ratio $(60: 1)$ between different substrates. Means followed by same italic lowercase letter indicate no statistical difference at the same $\mathrm{C} / \mathrm{N}$ ratio (90:1) between different substrates. Means followed by same uppercase letter indicate no statistical difference at the same substrate and different $\mathrm{C} / \mathrm{N}$ ratio

metabolizes easily degradable carbon sources such as soluble sugars (Fig. 3E) during initial composting stages (Sharma et al. 2000; Ryckeboer et al. 2003). Others metabolic events involved in the microbial activity during composting causes carbon and nitrogen losses, decreasing organic matter, $\mathrm{C} / \mathrm{N}$ ratio and crude energy (Bertoldi et al. 1983; Tuomela et al. 2000). Carbon is mainly lost by $\mathrm{CO}_{2}$ emission upon microbial respiration while nitrogen can be lost by $\mathrm{NH}_{3}$ emission or biologically recycled (Thambirajah et al. 1995; Ryckeboer et al. 2003).

Among different composting conditions applied in this study, 7 or 14 days of phase I with conditioning showed not statistical difference on mushroom yield and $\mathrm{BE}$ (Fig. 4). However, mushroom yield and BE in the substrates composted during 7 and 14 days without 
Fig. 6 Temperature of substrate (phase $\mathrm{I}$ ) and $\mathrm{C} / \mathrm{N}$ ratio changes in the different substrate formulations. aTemperature during phase I, substrates with supplementation (C/N ratio-60:1); b-

Temperature during phase I, substrates without supplementation $(\mathrm{C} / \mathrm{N}$ ratio90:1); $\mathbf{c}-\mathrm{C} / \mathrm{N}$ ratio changes during composting in the substrates with supplementation (C/N ratio-60:1); $\mathbf{d}-\mathrm{C} / \mathrm{N}$ ratio changes during composting in the substrates without supplementation ( $\mathrm{C} / \mathrm{N}$ ratio90:1). Substrates: SDECdecumbens grass; SCANsugarcane straw; SBRIbrizantha grass; SWHE-wheat straw
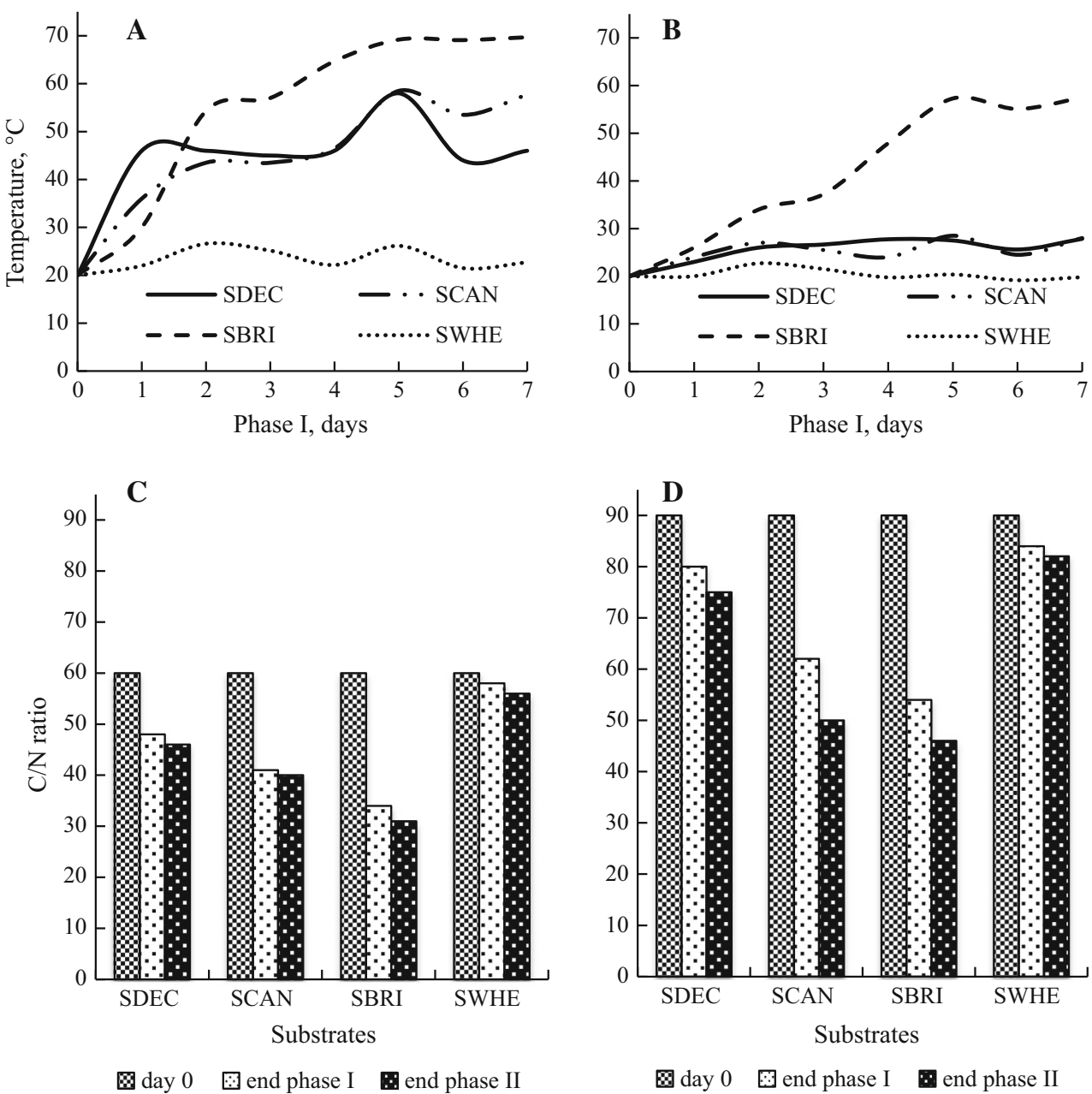

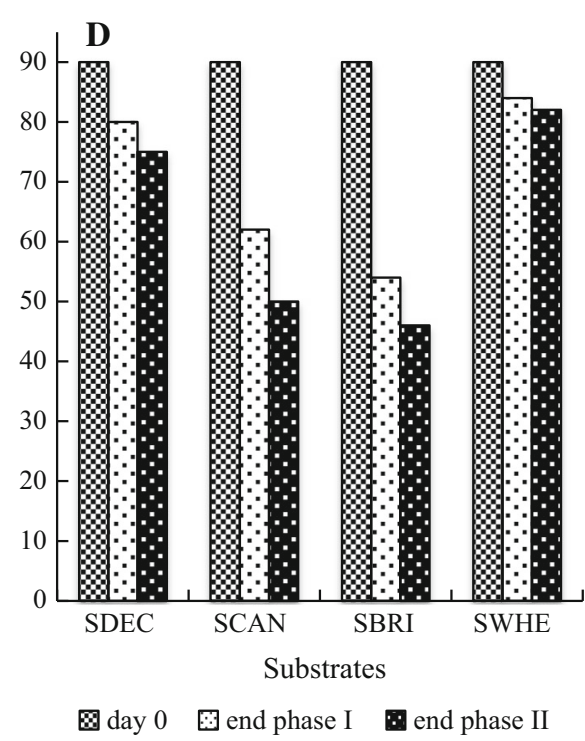

conditioning showed statistical difference (Fig. 4). The combination of shorter composting period (7 days) and conditioning step notably improved the mushroom yield and BE (24.04 and 100.54\%, respectively) (Fig. 4). The shorter composting ( 7 days) condition without conditioning showed be not enough composting time to prepare the substrate for oyster mushroom cultivation, while 7 days with conditioning (11 days, composting + conditioning) and 14 days with or without conditioning (14-18 days, respectively) improved the mushroom yield and BE. Hernández et al. (2003) testing a substrate based on $70 \%$ pangola grass (Digitaria decumbens), $30 \%$ coffee pulp and $2 \% \mathrm{Ca}(\mathrm{OH})_{2}$ composted under different conditions (3, 4 and 5 days) reported highest $\mathrm{BE}$ in the substrate composted for 3 days $(93.83 \%)$.

Among the raw materials tested with supplementation, brizantha grass showed higher mushroom yield $(28.5 \%)$ and BE (123.95\%) and, substrates without supplementation, decumbens grass showed higher mushroom yield $(18.97 \%)$ and sugarcane straw higher BE (84.92\%) (Fig. 5). Obodai et al. (2003) testing different substrate formulations (fresh sawdust, composted sawdust, rice husk, corn husk, banana leaves, maize stover, rice straw and elephant grass) by sterilization method reported highest BE $(61.04 \%)$ in the substrate based on composted sawdust (28 days of composting previously). The higher temperature (self-heating) during composting (Fig. 6a, b) and C/N ratio reduction (Fig. 6c, d) indicates brizantha grass as easily metabolized during composting (microbial activity). On the other hand, wheat straw substrate showed low temperature during composting (Fig. 6a, b), a slight decrease of $\mathrm{C} / \mathrm{N}$ ratio (Fig. 6c, d) and smaller yield and $\mathrm{BE}$ (Fig. 5). Sugarcane straw and decumbens grass showed mushroom yield similar with a commercial production $(24.22 \%)$ in substrate based on wheat straw and alfalfa ( $5 \% \mathrm{w} / \mathrm{w}$ of dry straw) composted for 7 days followed by pasteurization and conditioning (Vajna et al. 2010). The sugarcane straw has a big potential in Brazil to be used in the mushroom industry because sugar/ethanol industry generate millions of tons every year (Santos et al. 2012).

Substrate supplementation with an organic nitrogen source (wheat bran) increases yield and BE (Fig. 5). The main reason is because organic nitrogen sources are easily metabolized by oyster mushroom (Curvetto et al. 2002; 
Bonatti et al. 2004; Rizki and Tamai 2011). In addition, metabolizing easy degradable carbon sources (wheat bran) is energetically efficient than breakdown complex carbohydrate as cellulose, hemicellulose and lignin (Nunes et al. 2012). Zervakis et al. (2013) testing different supplementation levels (20, 40 and $60 \%$ ) of composted (90 days) and noncomposted raw olive mill waste in a substrate based on wheat straw (sterile substrate) reported BE of $135.34 \%$ (substrate supplemented with $5 \%$ of wheat bran plus $20 \%$ of olive mill waste composted, $\mathrm{C} / \mathrm{N}$ ratio of 40:1). Philippoussis et al. (2001) tested wheat straw, cotton waste and peanut shell supplemented with wheat bran $(\mathrm{C} / \mathrm{N}$ ratio between 30 and 60:1) through sterilization method $(1.5 \mathrm{~h}$ at $1.1 \mathrm{~atm})$ reported highest $\mathrm{BE}$ of 116.70 and $70.61 \%$ for two commercial strains of $P$. ostreatus, HK35 and P69, respectively. Comparisons with other studies were hindered by the fact that most of them were carried out using laboratory model conditions (small bags and high spawn concentration), different substrate preparation methods (sterilization, only pasteurization by steam or unpasteurized substrate), different strains, different production condition etc.

\section{Conclusions}

Seven days of composting with conditioning showed higher mushroom yield and biological efficiency, as well as low environmental pollution (less emission of $\mathrm{NH}_{3}$ and $\mathrm{CO}_{2}$ ). In addition, shorter composting period contribute to reduce cost production. Brizantha grass and sugarcane straw showed potential to be applied for oyster mushroom industry. Supplementation of composted substrate improved yield and biological efficiency of mushroom. Looking forward, future research should include microbial community activity and carbohydrates changes during composting process and its effects on oyster mushroom yield.

Acknowledgments This research was supported by Coordination for the Improvement of Higher Level Personnel (CAPES Foundation), No. 005707/2012-05. We are grateful to Graduate Program (Energy in Agriculture) of College of Agronomic Sciences, Sao Paulo State University, for constantly financial support.

\section{References}

Bertoldi M, Vallini G, Pera A (1983) The biology of composting: a review. Wast Manag Res 1(2):157-176

Bonatti M, Karnopp P, Soares HM, Furlan SA (2004) Evaluation of Pleurotus ostreatus and Pleurotus sajor-caju nutritional characteristics when cultivated in different lignocellulosic wastes. Food Chem 88(3):425-428

Brasil (2007) Ministério da Agricultura, Pecuária e Abastecimento Manual de métodos analíticos oficiais para fertilizantes minerais, orgânicos, organominerais e corretivos. http://www.agricultura.
pr.gov.br/arquivos/File/PDF/in_28_07_anexo.pdf. Accessed 25 May 2013

Chang ST, Miles PG (2004) Mushrooms: cultivation, nutritional value, medicinal effect, and environmental impact. CRC Press, Boca Raton

Choi KW (2007) Shelf cultivation of oyster mushroom. In: MushWorld (ed) Mushroom growers' handbook 1. Oyster mushroom cultivation, MushWorld-Heineart Inc, Seoul

Curvetto NR, Figlas D, Devalis R, Delmastro S (2002) Growth and productivity of different Pleurotus ostreatus strains on sunflower seed hulls supplemented with $\mathrm{N}-\mathrm{NH}_{4}{ }^{+}$and/or MN (II). Bioresour Technol 84(2):171-176

Hernández D, Sánchez JE, Yamasaki K (2003) A simple procedure for preparing substrate for Pleurotus ostreatus cultivation. Bioresour Technol 90:145-150

Johnson RR, Balwani TL, Johnson LJ, McClume KE, Dehority BA (1966) corn plant maturity II. Effect on In vitro cellulose digestibility and soluble carbohydrate content. J Anim Sci 25:617-623

Lee HY, Won-Rok K, Min BH (2002) Automation of solid-state bioreactor for Oyster Mushroom composting. Microbiol 30:228-232

Lyons GA, Sharma HSS, Kilpatrick M, Cheung L, Moore S (2006) Monitoring of changes in substrate characteristics during mushroom compost production. J Agric Food Chem 54:4658-4667

Nunes MD, Da Luz JMR, Paes SA, Ribeiro JJO, Silva MCS, Kasuya MCM (2012) Nitrogen supplementation on the productivity and the chemical composition of oyster mushroom. J food Res 1(2):113-119

Obodai M, Cleland-Okine J, Vowotor KA (2003) Comparative study on the growth and yield of Pleurotus ostreatus mushroom on different lignocellulosic by-products. J Ind Microbiol Biotechnol 30:146-149

Oei P (2003) Mushroom cultivation. Backhuys Publishers, Leiden

Philippoussis A, Zervakis G, Diamantopoulou P (2001) Bioconversion of agricultural lignocellulosic wastes through the cultivation of the edible mushrooms Agrocybe aegerita, Volvariella volvacea and Pleurotus spp. World J Microbiol Biotechnol 17:191-200

Rizki M, Tamai Y (2011) Effects of different nitrogen rich substrates and their combination to the yield performance of oyster mushroom (Pleurotus ostreatus). World J Microbiol Biotechnol 27:1695-1702

Royse DJ (2013) Trends in Mushroom production worldwide. In: Sales-Campos C, Abreu RLS, Vianez BF, Urben AF (eds) Anais do VII Simpósio internacional sobre cogumelos no Brasil, 6th edn. Embrapa, Brasilia, pp 38-47

Royse DJ, Schisler LC (1987) Yield and size of Pleurotus ostreatus and Pleurotus sajor- caju as effected by delayed-release nutrient. Appl Microbiol Biotechnol 26(2):191-194

Royse DJ, Rhodes TW, Ohga S, Sanchez JE (2004) Yield, mushroom size and time to production of Pleurotus cornucopiae (oyster mushroom) grown on switch grass substrate spawned and supplemented at various rates. Bioresour Technol 91(1):85-91

Ryckeboer J, Mergaert J, Vaes K, Klammer S, De Clercq D, Coosemans J, Insam H, Swings J (2003) A survey of bacteria and fungi occurring during composting and self-heating processes. Ann Microbiol 53(4):349-410

Sánchez C (2010) Cultivation of Pleurotus ostreatus and other edible mushroom. Appl Microbiol Biotechnol 80:1321-1337

Santos FA, Queiróz JH, Colodette JL, Fernandes SA, Guimarãrs VM, Rezende ST (2012) Potential of sugarcane straw for ethanol production. Quim Nova 35(5):1004-1010

Sharma HSS, Lyons G, Chambers J (2000) Comparison of the changes in mushroom (Agaricus bisporus) compost during 
windrow and bunker stages of phase I and II. Ann Appl Biol 136(1):59-68

Sinden JW, Hauser E (1950) The short method of composting. Mushroom Sci 1:52-59

Straatsma G, Samson RA, Olijnsma TW, Op Den Camp HJM, Gerrits JPG, Van Griensven LJLD (1994) Ecology of thermophilic fungi in mushroom compost, with emphasis on Scytalidium thermophilum and growth stimulation of Agaricus bisporus mycelium. Appl Environ Microbiol 60(2):454-458

Straatsma G, Gerrits JPG, Thissen JTNM, Amsing JGM, Loeffen H, Van Griensven LJLD (2000) Adjustment of the composting process for mushroom cultivation based on initial substrate composition. Bioresour Technol 72(1):67-74

Thambirajah JJ, Zulkali MD, Hashim MD (1995) Microbiological and biochemical changes during the composting of oil palm emptyfruit-bunches. Effect of nitrogen supplementation on the substrate. Bioresour Technol 52(2):133-144
Tuomela M, Vikman M, Hatakka A, Itavaara M (2000) Biodegradation of lignin in a compost environment: a review. Bioresour Technol 72(2):169-183

Vajna B, Nagy A, Sajben E (2010) Microbial community structure changes during oyster mushroom substrate preparation. Appl Microbiol Biotechnol 86:367-375

Van Griensven LJLD (1988) The cultivation of mushrooms. Rustington, Sussex

Vieira FR, Pereira DM, Andrade MCN, Minhoni MTA (2012) Molecular characterization of Pleurotus ostreatus commercial strains by random amplified polymorphic DNA (RAPD). Afr J Agric Res 8(24):3146-3150

Zervakis GI, Koutrotsios G, Katsaris P (2013) Composted versus raw olive mill waste as substrate for the production of medicinal mushrooms: an assessment of selected cultivation and quality parameters. Biomed Res Int. doi:10.1155/2013/546830 